\title{
Disain Fasilitas Pergerakan Kedatangan Penumpang di Terminal Bandara New Yogyakarta International Airport
}

\author{
Catharina Tiffani Wulandari, Ervina Ahyudanari, Anak Agung Gde Kartika, Cahya Buana, dan Catur Arif Prastyanto \\ Departemen Teknik Sipil, Fakultas Teknik Sipil, Lingkungan dan Kebumian, Institut Teknologi Sepuluh Nopember (ITS) \\ e-mail:ervina@ce.its.ac.id
}

\begin{abstract}
Abstrak-Bandara baru yang diberi nama New Yogyakarta International Airport terletak di Kabupaten Kulonprogo, tepatnya di Kecamatan Temon. Bandara ini diharapkan dapat mengimbangi pesatnya pertumbuhan kebutuhan transportasi udara di Yogyakarta, serta meningkatkan kenyamanan dan pelayanan bagi para pengguna jasa transportasi udara. Seiring dengan perkembangan lalu lintas, perlu diimbangi dengan fasilitas yang memadai guna memproses pergerakan penumpang menuju ruang pemrosesan selanjutnya. Oleh karena itu, disediakan fasilitas yang bertujuan untuk mempercepat proses pergerakan penumpang menuju ruang pemrosesan selanjutnya. Hal ini memungkinkan penumpang yang hendak mengambil bagasi, tiba lebih cepat di baggage claim area dari bagasi yang akan diambil. Waktu yang lebih cepat ini akan menyebabkan penumpang harus menunggu lagi. Dalam studi ini mencoba memberikan solusi masalah tersebut dengan memperhatikan proses penanganan bagasi. Berdasarkan hasil analisis peramalan jumlah penumpang menggunakan metode Regresi Linear, diperkirakan jumlah penumpang di Bandara NYIA pada tahun 2038 yaitu 20,000,000 penumpang. Total luas terminal penumpang diperkirakan adalah $97,000 \mathrm{~m}^{2}$. Didapatkan waktu penumpang menunggu di baggage claim area dengan memperhatikan proses penanganan bagasi yaitu 23,69 menit untuk domestik \& 23,19 menit untuk internasional. Hasil tersebut memenuhi standar pelayanan pengguna jasa bandar udara (Permenhub No. 38/2015) yang menyatakan bahwa standar waktu menunggu penumpang mengambil bagasi di baggage claim area adalah 30 menit
\end{abstract}

Kata Kunci- terminal bandara, tingkat pelayanan, jarak berjalan, waktu pemrosesan

\section{PENDAHULUAN}

$\mathrm{P}$ ada saat ini, adanya perkembangan perekonomian di Kota Yogyakarta menyebabkan meningkatnya aktifitas di Bandara Adisutjipto hingga melebihi batas daya tampung penumpang di bandara tersebut. Oleh karena itu, Menteri Perhubungan bersama dengan Gubernur Daerah Istimewa Yogyakarta memutuskan untuk memindahkan Bandara ke Kabupaten Kulonprogo, tepatnya di Kecamatan Temon dan diberi nama New Yogyakarta International Airport (NYIA) dan nantinya Bandara Adisutjipto akan digunakan kembali oleh TNI Angkatan Udara untuk kepentingan militer [1]. Pembangunan Bandar Udara baru harus ditunjang dengan pembangunan fasilitas yang memadai guna memproses pergerakan penumpang menuju ruang pemrosesan selanjutnya.

Kemudahan akses \& sistem sirkulasi merupakan hal yang sangat berpengaruh pada kelancaran aktivitas dan kenyamanan pengguna bandar udara. Fasilitas yang disediakan bertujuan untuk mempercepat proses pergerakan penumpang menuju ruang pemrosesan selanjutnya. Hal ini memungkinkan penumpang yang hendak mengambil bagasi, tiba lebih cepat di baggage claim area dari bagasi yang akan diambil. Waktu yang lebih cepat ini akan menyebabkan penumpang harus menunggu lagi. Dalam studi ini mencoba memberikan solusi masalah tersebut dengan memperhatikan proses penanganan bagasi.

Pembangunan Bandara New Yogyakarta International Airport (NYIA) merupakan usaha pemerintah dalam meningkatkan pelayanan pada penumpang pesawat yang semakin meningkat setiap tahunnya [2]. Perkembangan suatu bandara perlu didukung suatu perencanaan yang dapat memfasilitasi setiap perkembangan yang ada. Fasilitas tersebut bertujuan untuk memberikan kenyamanan bagi penumpang di bandara. Beberapa masalah yang akan dibahas antara lain:

- Bagaimana pertumbuhan jumlah penumpang di Bandara New Yogyakarta International Airport dalam waktu 20 tahun ke depan?

- Berapa kebutuhan luas masing-masing fasilitas terminal kedatangan (passport control area, baggage claim area,hall kedatangan, dan kerb kedatangan) yang dibutuhkan untuk menampung penumpang di tahun 2038 ?

- Berapa lama waktu yang dibutuhkan untuk proses pergerakan penumpang menuju ruang baggage claim area?

- Berapa lama waktu yang dibutuhkan untuk pemrosesan bagasi?

\section{METODE PENELITIAN}

Metodologi yang digunakan dalam studi ini dimulai dengan pengumpulan data jumlah penumpang dari PT. Angkasa Pura I (Persero). Data yang diperoleh diolah menggunakan metode forecasting untuk mendapatkan jumlah penumpang di tahun rencana yang dapat digunakan untuk menghitung kebutuhan luasan terminal. Dari hasil analisis tersebut dapat diperkirakan layout terminal penumpang untuk memudahkan akses pergerakan penumpang menuju baggage claim area (Gambar $1)$.

\section{HASIL DAN PEMBAHASAN}

Kenyamanan penumpang tergantung pada fasilitas yang disiapkan bandara. Kesiapan fasilitas pemrosesan pada setiap kegiatan dapat didekati dengan analisis pergerakan penumpang dan disain luasan fasilitas dengan mengikuti jumlah penumpang pada tahun rencana. 


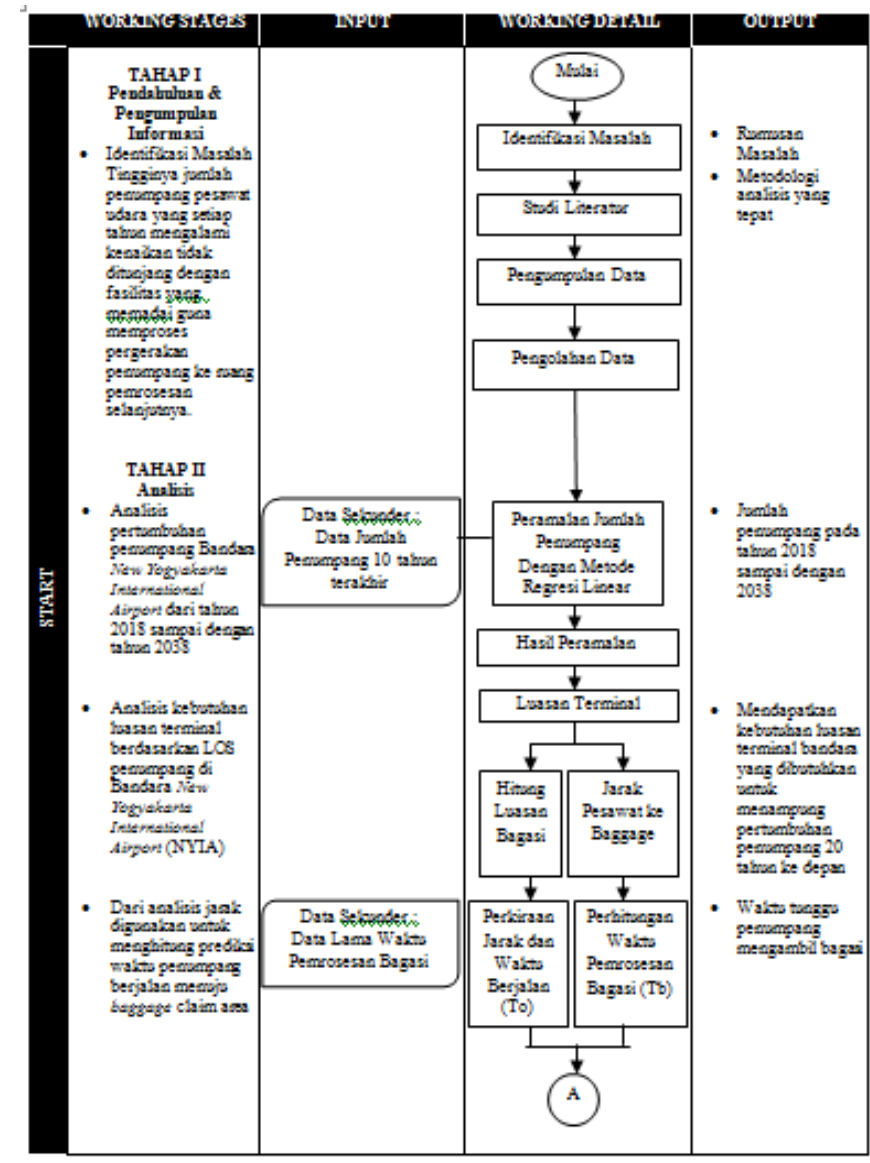

Gambar 1. Diagram alir metodologi.

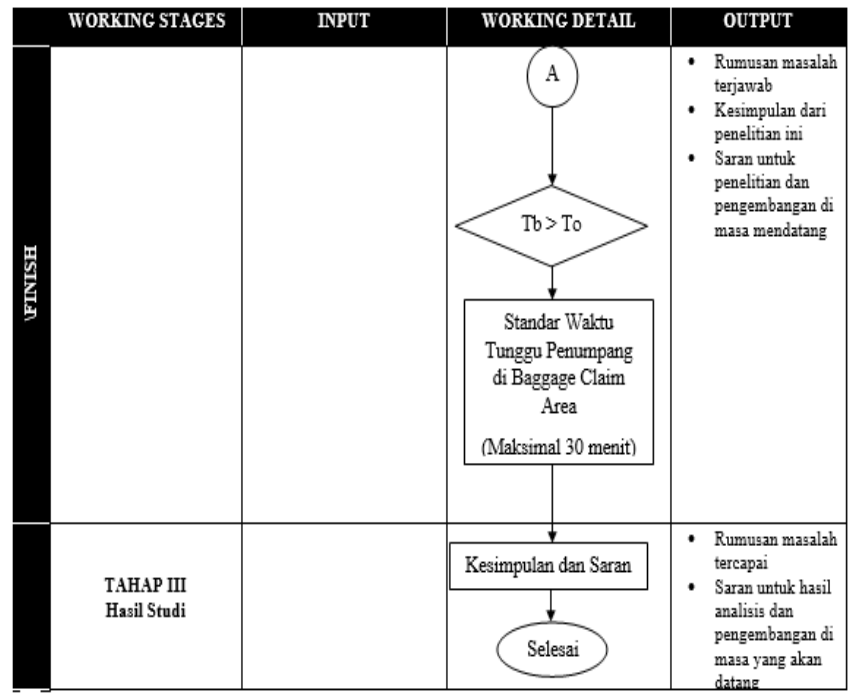

Gambar 1. Lanjutan diagram alir metodologi.

Dari hasil tersebut kemudian dievaluasi dengan ketentuan jarak berjalan dan lama pemrosesan. Secara detil, proses tersebut disajikan dalam subbab berikut:

\section{A. Pergerakan Penumpang Bandara Adisutjipto}

Volume pergerakan penumpang di Bandara Adisutjipto Yogyakarta 10 tahun terakhir mengalami trend yang semakin meningkat dan memiliki kecenderungan untuk semakin meningkat pada masa yang akan datang.

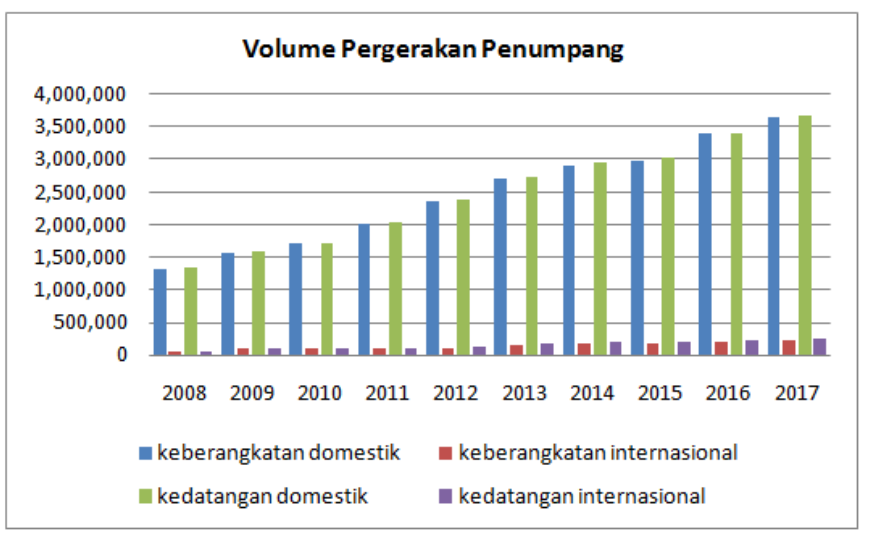

Gambar 2. Volume Pergerakan Penumpang

Gambar 2 menunjukkan peningkatan rata-rata sebesar 4,76\% per tahun.

\section{B. Peramalan Jumlah Penumpang Regresi Linear}

Peramalan jumlah penumpang diperlukan sebagai upaya untuk memperkirakan peningkatan jumlah penumpang di suatu bandara. Dalam studi ini, peramalan jumlah penumpang di Bandara Adisutjipto Yogyakarta digunakan untuk mengetahui jumlah penumpang di Bandara New Yogyakarta International Airport tahun 2038. Hasil peramalan akan digunakan untuk menganalisis kebutuhan luasan terminal penumpang.

Data pertumbuhan penumpang seperti pada Gambar 2 kemudian diramalkan menggunakan regresi linear untuk masing-masing pergerakan penumpang. Hasil peramalan tersebut ditunjukkan pada Tabel 1.

Tabel 1.

Hasil Peramalan Penumpang

\begin{tabular}{|c|c|c|c|}
\hline Pergerakan Penumpang & Persamaan Regresi & $\mathrm{R}^{2}$ & $\sum$ tahun 2038 \\
\hline Keberangkatan Domestik & $Y=263607 x+1012308$ & 0.99 & $9,184,149$ \\
\hline $\begin{array}{c}\text { Keberangkatan } \\
\text { Internasional }\end{array}$ & $Y=18771 x+31213$ & 0.95 & 613,118 \\
\hline Kedatangan Domestik & $Y=263243 x+1036206$ & 0.99 & $9,196,767$ \\
\hline Kedatangan Internasional & $Y=19584 x+40536$ & 0.95 & 647,650 \\
\hline \multicolumn{3}{|c|}{ Total Penumpang } & $20,000,000$ \\
\hline
\end{tabular}

\section{Perhitungan Peak Hour Tahun Rencana}

Penumpang peak hour merupakan indikator kepadatan maksimal dalam suatu fasilitas transportasi. Indikator ini diperlukan untuk menentukan fasilitas penumpang di bandara. Untuk tahun rencana, digunakan perkiraan peak hour penumpang dari koefisien pengali yang distandarkan pada FAA [3]. Peak hour diperoleh dengan mengalikan jumlah penumpang tahunan hasil peramalan dengan persentase nilai TPHP (Typical Peak Hour Passenger). Hasil perhitungan jumlah penumpang saat peak hour di Bandara New Yogyakarta International Airport pada tahun 2038 yaitu:

- Keberangkatan

= jumlah penumpang keberangkatan $\mathrm{x}$ TPHP\%

$=9,797,267 \times 0.04 \%$

$=3,919$ penumpang

- Kedatangan

$=$ jumlah penumpang kedatangan $\mathrm{x}$ TPHP\%

$=9,844,417 \times 0.04 \%$

$=3,938$ penumpang 


\section{Luasan Terminal Penumpang}

Kebutuhan luasan terminal penumpang didasarkan pada jumlah penumpang tahunan yang akan dilayani oleh bandara tersebut pada tahun perencanaan. Kebutuhan luasan terminal dibagi menjadi 2 yaitu terminal penumpang keberangkatan \& terminal penumpang kedatangan. Perhitungan kebutuhan luasan, rumus diperoleh dari standar International Air Transport Association (2004) [4].

Luasan terminal yang diperlukan adalah terminal keberangkatan dan kedatangan. Walaupun yang di studi dalam artikel ini adalah fasilitas kedatangan tetapi yang diperlukan adalah jarak berjalan terjauh yang dipengaruhi luasan terminal total.

- Terminal Penumpang Keberangkatan

Disain terminal bandara yang baik didapatkan dari pendisain bandara yang mengerti alur penumpang dan barang di terminal bandara. Pada terminal keberangkatan, jalur penumpang bervariasi tergantung pada penumpang check-in dan transportasinya maupun tidak memiliki bagasi. Berikut merupakan alur pergerakan penumpang keberangkatan yaitu:

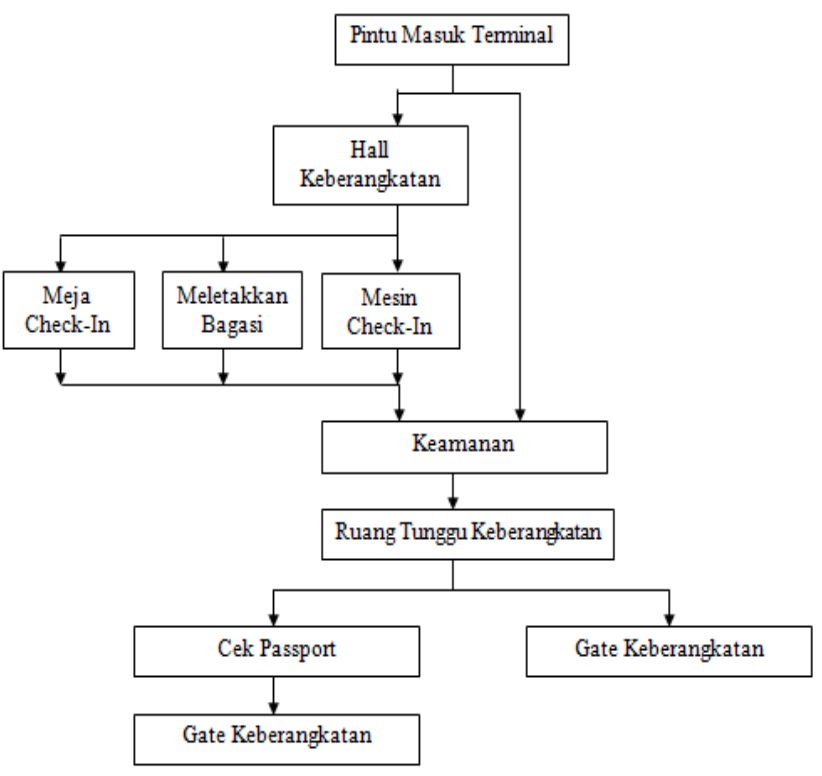

Gambar 3. Alur terminal penumpang keberangkatan.

Dengan mengikuti persamaan perhitungan luasan pada IATA [4] maka diperoleh fasilitas pada terminal keberangkatan sebagai berikut:

$\begin{array}{ll}\text { Kerb Keberangkatan } & : 393 \mathrm{~m} \\ \text { Hall Keberangkatan } & : 10346 \mathrm{~m}^{2} \\ \text { Pemeriksaan Security (Terpusat): } 16 \mathrm{unit}^{2} \\ \text { Check In - Area } & : 1207 \mathrm{~m}^{2} \\ \text { Check In - Counter } & : 172 \text { desk } \\ \text { Passport Area } & : 1176 \mathrm{~m}^{2} \\ \text { Passport Control } & : 43 \text { positions } \\ \text { Ruang Tunggu Keberangkatan } & : 5473 \mathrm{~m}^{2} \\ \text { Tempat Duduk } & : 1306 \mathrm{unit}^{2} \\ \text { Gate Hold Room } & : 5600 \mathrm{~m}^{2} \\ \text { Toilet } & : 862 \mathrm{~m}^{2} \\ \text { Ruang Sirkulasi } & : 17400 \mathrm{~m}^{2} \\ \text { Gudang } & : 1262 \mathrm{~m}^{2}\end{array}$

Total kebutuhan luas terminal penumpang keberangkatan di Bandara New Yogyakarta International Airport pada tahun
2038, langkah awal adalah menjumlahkan luasan fasilitas terminal yang sudah dihitung lalu hasil perhitungan tersebut dikalikan dengan proporsi untuk ruang konsesi dan struktur bangunan. Dalam studi ini, diasumsikan proporsi ruang ruang konsesi sebesar 20\% dan struktur bangunan sebesar 5\% dari luas terminal [5].

Hasil perhitungan total luas terminal penumpang keberangkatan dapat dilihat seperti berikut ini:

Total Luas = luas terminal+ruang konsesi+struktur bangunan

$$
\begin{aligned}
& =43326+(43326 \times 20 \%)+(43326 \times 5 \%) \\
& =54158 \mathrm{~m}^{2} \approx 55000 \mathrm{~m}^{2}
\end{aligned}
$$

- Terminal Penumpang Kedatangan

Disain setelah pesawat mendarat, penumpang dapat mengikuti dua jalur yang berbeda yaitu naik ke penerbangan lain atau meninggalkan bandara. Berikut merupakan alur pergerakan penumpang kedatangan yaitu:

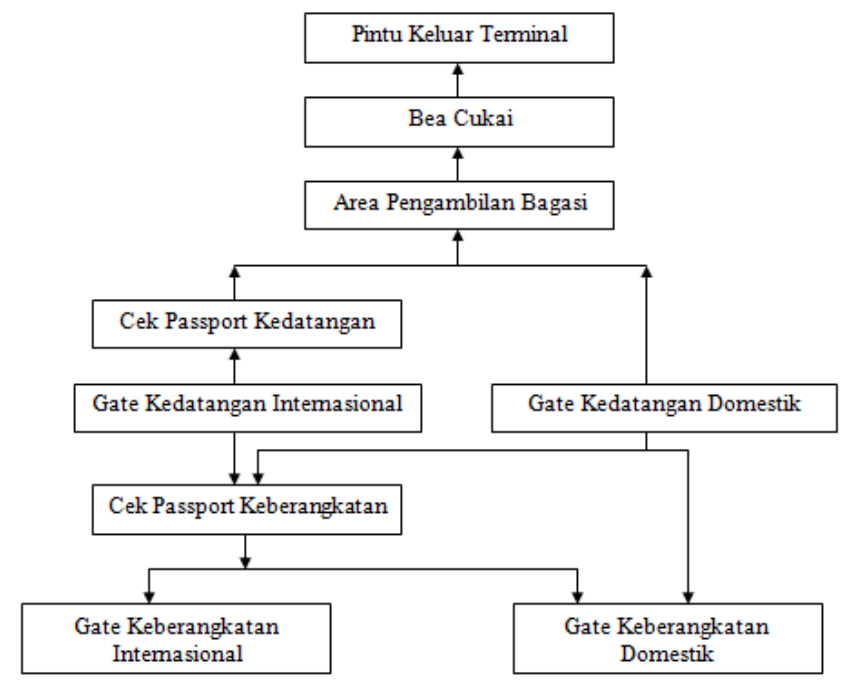

Gambar 4. Alur terminal penumpang kedatangan.

Dengan cara yang sama maka diperoleh luasan fasilitas kedatangan sebagai berikut:

Baggage Claim Devices :

- Wide-Body Aircraft : 2 devices

- Narrow-Body Aircraft : 11 devices

Baggage Claim Area $\quad: 4082 \mathrm{~m}^{2}$

Passport Area $\quad: 1181 \mathrm{~m}^{2}$

Passport Control : 43 positions

Hall Kedatangan $\quad: 8447 \mathrm{~m}^{2}$

Kerb Kedatangan $\quad: 395 \mathrm{~m}$

Toilet $\quad: 866 \mathrm{~m}^{2}$

Ruang Sirkulasi $\quad: 17484 \mathrm{~m}^{2}$

Gudang : $962 \mathrm{~m}^{2}$

Total kebutuhan luas terminal penumpang kedatangan di Bandara New Yogyakarta International Airport pada tahun 2038, langkah awal adalah menjumlahkan luasan fasilitas terminal yang sudah dihitung lalu hasil perhitungan tersebut dikalikan dengan proporsi untuk ruang konsesi dan struktur bangunan. Dalam tugas akhir ini, diasumsikan proporsi ruang ruang konsesi sebesar 20\% dan struktur bangunan sebesar 5\% dari luas terminal [5]. 
Hasil perhitungan total luas terminal penumpang kedatangan dapat dilihat seperti berikut ini:

Total Luas = luas terminal+ruang konsesi+struktur bangunan

$$
=33022+(33022 \times 20 \%)+(33022 \times 5 \%)
$$$$
=41278 \mathrm{~m}^{2} \approx 42000 \mathrm{~m}^{2}
$$

Hasil perhitungan total luasan terminal penumpang NYIA dapat dilihat seperti berikut ini:

Luas Terminal $=$ Luas Keberangkatan + Luas Kedatangan

$$
=55000 \mathrm{~m}^{2}+42000 \mathrm{~m}^{2}
$$$$
=97000 \mathrm{~m}^{2}
$$

Maka total luas terminal penumpang yang dibutuhkan di Bandara New Yogyakarta International Airport adalah 97000 $\mathrm{m}^{2}$ dengan kapasitas penumpang bandara 20 juta penumpang di tahun 2038.

\section{E. Disain Terminal Penumpang}

Dalam menentukan fasilitas pergerakan penumpang pada terminal kedatangan perlu memperhatikan jarak berjalan penumpang dari gate kedatangan menuju ruang pengambilan bagasi. Posisi gate tidak dapat dipastikan. Oleh karena itu jarak berjalan diperkirakan dari posisi gate terjauh.

Berdasarkan hasil perhitungan kebutuhan luasan terminal penumpang, dapat diperkirakan disain layout terminal penumpang di Bandara New Yogyakarta International Airport (NYIA) sebagai berikut:

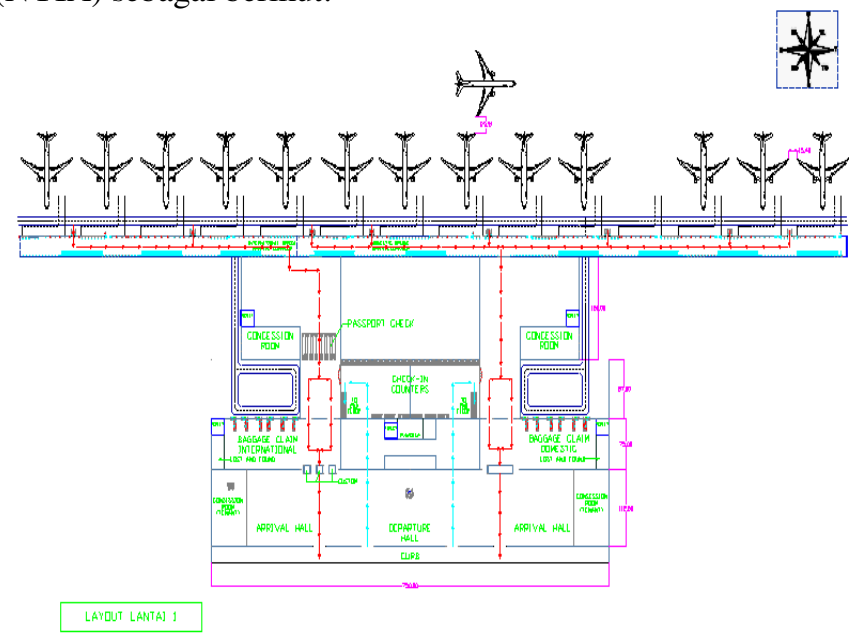

Gambar 5. Disain Layout Terminal NYIA Lantai 1.

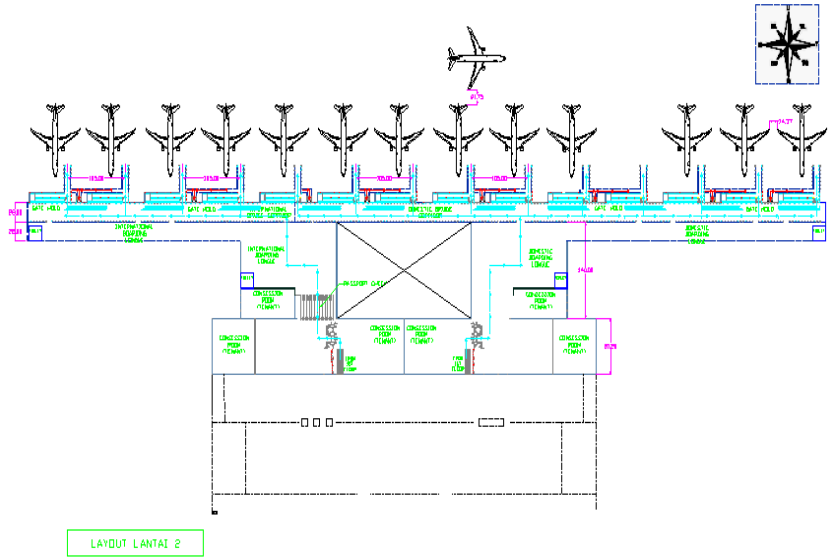

Gambar 6. Disain Layout Terminal NYIA Lantai 2
Dari disain layout terminal dapat diketahui jarak berjalan penumpang terjauh antar fasilitas di Bandara NYIA. Dengan asumsi kecepatan pejalan kaki adalah $1,27 \mathrm{~m} / \mathrm{s}$, dapat diketahui waktu tempuh yang dibutuhkan di terminal penumpang Bandara NYIA [6].

Tabel 2.

\begin{tabular}{|c|c|c|c|c|}
\hline \multirow{2}{*}{ TERMINAL } & \multicolumn{2}{|c|}{ "FASILITAS } & \multirow{2}{*}{$\begin{array}{c}\text { JARAK } \\
\text { BERJALAN } \\
(\mathrm{m})\end{array}$} & \multirow{2}{*}{$\begin{array}{c}\text { WAKTU } \\
\text { TEMPUH } \\
\text { (s) }\end{array}$} \\
\hline & DARI & $\mathrm{KE}$ & & \\
\hline \multirow{4}{*}{ Keberangkatan } & & DOMESTIK & & \\
\hline & Hall & Check-In & 200 & 157 \\
\hline & Check-In & $\begin{array}{l}\text { Ruang } \\
\text { Tunggu }\end{array}$ & 670 & 528 \\
\hline & $\begin{array}{l}\text { Ruang } \\
\text { Tunggu }\end{array}$ & Gate & 20 & 16 \\
\hline \multirow{3}{*}{ Kedatangan } & Gate & Pesawat & 50 & 39 \\
\hline & Pesawat & $\begin{array}{l}\text { Baggage } \\
\text { Claim }\end{array}$ & 775 & 610 \\
\hline & $\begin{array}{l}\text { Baggage } \\
\text { Claim }\end{array}$ & Hall & 220 & 173 \\
\hline \multirow{5}{*}{ Keberangkatan } & & TERNASIONAI & & \\
\hline & $\begin{array}{c}\text { Hall } \\
\text { Check-In }\end{array}$ & $\begin{array}{l}\text { Check-In } \\
\text { Immigration }\end{array}$ & $\begin{array}{l}200 \\
165\end{array}$ & $\begin{array}{l}157 \\
130\end{array}$ \\
\hline & Immigration & $\begin{array}{l}\text { Ruang } \\
\text { Tunggu }\end{array}$ & 415 & 327 \\
\hline & $\begin{array}{c}\text { Ruang } \\
\text { Tunggu }\end{array}$ & Gate & 20 & 16 \\
\hline & Gate & Pesawat & 50 & 39 \\
\hline \multirow{3}{*}{ Kedatangan } & Pesawat & Immigration & 485 & 382 \\
\hline & Immigration & $\begin{array}{c}\text { Baggage } \\
\text { Claim }\end{array}$ & 180 & 142 \\
\hline & $\begin{array}{c}\text { Baggage } \\
\text { Claim }\end{array}$ & Hall & 220 & 173 \\
\hline
\end{tabular}

Hasil Analisis Jarak Berjalan dan Waktu Tempuh

Berdasarkan hasil analisis jarak berjalan terjauh dari terminal kedatangan domestik, didapatkan jarak perpindahan penumpang dari pesawat menuju ke baggage claim adalah 775 $\mathrm{m}$. Sedangkan jarak berjalan terjauh dari terminal kedatangan internasional, didapatkan jarak perpindahan penumpang dari pesawat ke immigration adalah $485 \mathrm{~m}$.

Berdasarkan standar IATA (2004), jarak berjalan antar fasilitas yang paling jauh untuk penumpang berjalan kaki agar penumpang tetap merasa nyaman adalah $300 \mathrm{~m}$ [4]. Oleh karena itu, perlu adanya fasilitas travellator untuk membantu penumpang berjalan agar tetap merasa nyaman. Travellator yang digunakan menggunakan tipe Mitsubishi TP-E model 1200 dengan kapasitas 12000 orang/jam dengan kecepatan 40 $\mathrm{m} /$ min dengan jumlah penumpang peak hour keberangkatan 3919 penumpang dan kedatangan 3938 penumpang, maka dengan spesifikasi travellator yang dipakai tersebut dapat digunakan. Fasilitas travellator ini akan dipasang dengan panjang sebagai berikut:

Panjang travellator $=$ jarak berjalan - standar jarak berjalan

Jarak berjalan ini diperoleh dari Tabel 2 sedangkan standar jarak berjalan ini adalah standar IATA [4].

- Kedatangan Domestik

$$
\begin{aligned}
& =775 \mathrm{~m}-300 \mathrm{~m} \\
& =475 \mathrm{~m}
\end{aligned}
$$

- Kedatangan Internasional

$$
\begin{aligned}
& =485 \mathrm{~m}-300 \mathrm{~m} \\
& =185 \mathrm{~m}
\end{aligned}
$$


Jadi, total waktu yang dibutuhkan penumpang berjalan dengan menggunakan travellator yaitu:

- Kedatangan Domestik

$$
\begin{aligned}
& \mathrm{T}=\frac{\text { panjang travellator }}{(\text { kec. travellator }+ \text { kec. orang berjalan })} \\
& \mathrm{T}=\frac{475 \mathrm{~m}}{(0,67 \mathrm{~m} / \mathrm{s}+1,27 \mathrm{~m} / \mathrm{s})}=245 \mathrm{~s}=5 \text { menit }
\end{aligned}
$$

- Kedatangan Internasional

$$
\begin{aligned}
& \mathrm{T}=\frac{\text { panjang travellator }}{(\text { kec. travellator }+ \text { kec. orang berjalan })} \\
& \mathrm{T}=\frac{185 \mathrm{~m}}{(0,67 \mathrm{~m} / \mathrm{s}+1,27 \mathrm{~m} / \mathrm{s})}=96 \mathrm{~s}=2 \text { menit }
\end{aligned}
$$

Waktu yang dibutuhkan pejalan kaki di terminal keberangkatan maupun kedatangan Bandara New Yogyakarta International Airport (NYIA) dari pesawat menuju ke baggage claim area tanpa menggunakan travellator sebagai berikut:

$$
\mathrm{T}=\frac{300 \mathrm{~m}}{1,27 \mathrm{~m} / \mathrm{s}}=236 \mathrm{~s}=4 \mathrm{menit}
$$

Jadi total waktu keseluruhan perpindahan penumpang dari pesawat menuju ke baggage claim area sebagai berikut:

- Kedatangan Domestik

$$
\begin{aligned}
& =\text { travellator }+ \text { tanpa travellator } \\
& =5 \text { menit }+4 \text { menit } \\
& =9 \text { menit }
\end{aligned}
$$

- Kedatangan Internasional

Pesawat ke immigration yaitu:

$=$ travellator + tanpa travellator + proses imigrasi

$=2$ menit +4 menit $+0,5$ menit

$=6,5$ menit

Immigration ke baggage claim area yaitu:

$=6,5$ menit +3 menit

$=9,5$ menit

Sedangkan waktu pemrosesan bagasi dapat dihitung menjadi 3 tahap sebagai berikut:

\section{- Keluar dari pesawat}

Waktu pemrosesan bagasi saat keluar pesawat memakai standar pesawat yaitu 15 menit unload baggage dengan jenis pesawat Garuda Indonesia B747-400 [7].

\section{- Pesawat ke Terminal}

Waktu pemrosesan bagasi dari pesawat menuju ke terminal dapat diproses menggunakan cart. Asumsi untuk kecepatan cart $10 \mathrm{~km} / \mathrm{jam}(2,78 \mathrm{~m} / \mathrm{s})$ [8]. $\mathrm{T}=\frac{\mathrm{S}}{\mathrm{V}}=\frac{800 \mathrm{~m}}{2,78 \mathrm{~m} / \mathrm{s}}=5$ menit

\section{- Terminal}

Waktu pemrosesan bagasi adalah 14,31 menit lalu di konversi untuk mendapatkan waktu pemrosesan sesuai di Bandara New Yogyakarta International Airport untuk mendapatkan total waktu dari tas pertama sampai tas terakhir selesai [9].

$$
=\frac{\text { lama waktu pemrosesan }}{\text { jumlah bagasi }} \times \text { jumlah bagasi }
$$

$$
=\frac{14,31}{451} \times 400=12,69 \text { menit }
$$

Jadi total lama waktu pemrosesan bagasi di Bandara New Yogyakarta International Airport adalah:

$=15$ menit +5 menit $+12,69$ menit

$=32,69$ menit

Dari analisis tersebut didapatkan waktu penumpang menunggu di baggage claim area dengan memperhatikan proses penanganan bagasi di Bandara New Yogyakarta International Airport dengan total waktu pemrosesan bagasi dikurangi total waktu perpindahan penumpang dari pesawat menuju baggage claim area sebagai berikut:

- Kedatangan Domestik

$=32,69$ menit -9 menit

$=23,69$ menit

- Kedatangan Internasional

$=32,69$ menit $-9,5$ menit

$=23,19$ menit

\section{KESIMPULAN}

A. Kesimpulan

- Berdasarkan hasil peramalan jumlah penumpang dengan menggunakan metode Regresi Linear, didapat perkiraan jumlah penumpang di Bandara New Yogyakarta International Airport pada tahun 2038 yaitu 20,000,000 penumpang, dengan total penumpang keberangkatan sebesar 9,797,267 penumpang dan total penumpang kedatangan sebesar 9,844,417 penumpang.

Dari hasil peramalan diketahui pertumbuhan penumpang pada tahun 2018-2038 mengalami peningkatan rata-rata sebesar $4,76 \%$.

- Total luas terminal penumpang keberangkatan adalah $55,000 \mathrm{~m}^{2}$ dengan total terminal penumpang kedatangan adalah 42,000 $\mathrm{m}^{2}$. Maka total luas terminal penumpang yang dibutuhkan di Bandara New Yogyakarta International Airport pada tahun rencana (2038) adalah 97,000 $\mathrm{m}^{2}$.

- Lama waktu tempuh yang dibutuhkan penumpang dari pesawat menuju ke baggage claim area sebagai berikut:

Kedatangan domestik 9 menit

Kedatangan internasional 9,5 menit

- Lama waktu pemrosesan bagasi yaitu 32,69 menit

Dari analisis tersebut didapatkan waktu penumpang menunggu di baggage claim area dengan memperhatikan proses penanganan bagasi di Bandara New Yogyakarta International Airport dengan total waktu pemrosesan bagasi dikurangi total waktu perpindahan penumpang dari pesawat menuju baggage claim area sebagai berikut:

Kedatangan domestik 23,69 menit

Kedatangan internasional 23,19 menit

Dari hasil tersebut memenuhi standar pelayanan pengguna jasa bandar udara (Permenhub No. 38/2015) yang menyatakan 
bahwa standar waktu tunggu paling lama bagasi penumpang adalah 30 menit.

\section{DAFTAR PUSTAKA}

[1] Angkasa Pura I, "Selayang Pandang New Yogyakarta International Airport (NYIA)," 2016. .

[2] Direktorat Jendral Perhubungan Udara, "Lalu Lintas Angkutan Udara: Lalu Lintas Penumpang," 2015. [Online]. Available: https://hubud.dephub.go.id/?id/edar.

[3] N. Ashford and P. H. Wright, Airport Engineering (3rd ed). New York: A Wiley-Interscience Publication, 1992.

[4] I. A. T. Association, Airport Development Reference Manual. Geneva, 2004

[5] Menteri Perhubungan Republik Indonesia, "Peraturan Menteri
Perhubungan Republik Indonesia Nomor: KM 20 Tahun 2005 tentang Pemberlakuan Standar Nasional Indonesia SNI 03-70462004 Mengenai Terminal Penumpang Bandar Udara Sebagai Standar Wajib,” 2005.

[6] Transportation Reasearch Board, "Highway Capacity Manual," 2000.

[7] Boeing Commercial Airplanes, "Airplane Characteristics For Airport Planning," 2002.

[8] D. J. P. Udara, Peraturan Direktur Jenderal Perhubungan Udara Nomor: SKEP/77/VI/2005 tentang Persyaratan Teknis Pengoperasian Fasilitas Teknik Bandar Udara. 2005.

[9] W. Ariesna, "Perencanaan Sistem Penanganan Bagasi pada Terminal 2 di Bandar Udara Internasional Juanda Surabaya," Surabaya, 2016. 